\title{
Middle Ordovician harknessellid brachiopods (Dalmanellidina) from the Mediterranean margin of Gondwana
}

\author{
JAIME REYES-ABRIL, ENRIQUE VILLAS, JUAN CARLOS GUTIÉRREZ-MARCO, \\ ANDREA JIMÉNEZ-SÁNCHEZ \& JORGE COLMENAR
}

\begin{abstract}
The family Harknessellidae Bancroft, 1928 (Orthida, Dalmanellidina) was designed to embrace an assemblage of species referred previously to Harknessella Reed, 1917, and included five genera known mainly from the Middle and Upper Ordovician of England. Herein, we suggest reassigning to this family the genus Cacemia Mitchell, 1974, widespread in the middle Darriwilian (upper Middle Ordovician) of the Iberian and Armorican massifs. Since its designation, Cacemia was placed among the dalmanellidin heterorthids, in spite of its strongly mucronate hinge line, which is totally unknown within this Mediterranean family. A new harknessellid has been identified from the upper Darriwilian beds of the Central Iberian Zone (Central Spain): Isabelella fascicostellata Reyes-Abril \& Villas gen. et sp. nov. It is similar to Horderleyella Bancroft, 1928 for its coarsely fascicostellate radial ornamentation and obtuse cardinal angles, although its convexoplane to convexoconcave profile allows discrimination from the typically dorsibiconvex Horderleyella. A phylogenetic analysis of the family places both Cacemia and Isabelella in basal positions of their clades, which fits with their early stratigraphic record. Based on our study, the family Harknessellidae appears to have originated in the high latitude Mediterranean margins of Gondwana during pre-Darriwilian times, before the detachment of Avalonia from Gondwana. The family reached its highest diversification in Avalonia throughout the Late Ordovician, keeping connections with the Mediterranean and Proto-Andean margins of Gondwana, as well as with the mid-latitude palaeocontinents of Baltica and South China. - Key words: Ordovician, brachiopods, Orthida, Iberian Peninsula, Spain, Gondwana.
\end{abstract}

ReYeS-Abril, J., Villas, E., GutiéRreZ-MARCo, J.C., JimÉneZ-SÁnCheZ, A. \& COlMEnAR, J. 2013. Middle Ordovician harknessellid brachiopods (Dalmanellidina) from the Mediterranean margin of Gondwana. Bulletin of Geosciences 88(4), 813-828 (7 figures, 1 table). Czech Geological Survey, Prague. ISSN 1214-1119. Manuscript received March 18, 2013; accepted in revised form July 2, 2013; published online September 12, 2013; issued October 31, 2013.

Jaime Reyes-Abril, Departamento de Geología General, Grupo TERRA, Facultad de Ingeniería, Universidad de Los Andes, Núcleo La Hechicera, Edificio Ingeniería, Piso 1, Ala Este, 5001 Mérida, Venezuela; jreyes@ula.ve•Enrique Villas (corresponding author) \& Jorge Colmenar, Área y Museo de Paleontología, Facultad de Ciencias, Universidad de Zaragoza,C/ Pedro Cerbuna 10,50009 Zaragoza,Spain; villas@unizar.es,colmenar@unizar.es・Juan Carlos Gutiérrez-Marco, Instituto de Geociencias (CSIC, UCM), Facultad de Ciencias Geológicas, José Antonio Novais 12, 28040 Madrid, Spain; jcgrapto@geo.ucm.es •Andrea Jiménez-Sánchez, Center of Biology, Geosciences and Environmental Education, University of West Bohemia, Klatovská 51, 30619 Plzen (Czech Republic); jimenez@cbg.zcu.cz

The family Harknessellidae Bancroft, 1928 (Orthida, Dalmanellidina) was designated to embrace an assemblage of species referred previously to Harknessella Reed, 1917, including five genera known mainly from the Middle and Upper Ordovician of England. Since its designation, only three new genera have been provisionally included within the family. The earliest record of the family is from the upper Middle Ordovician, but most of its genera are restricted to the Upper Ordovician, with only one possible record from the lower Silurian (Harper 2000).

The harknessellids have rarely been recorded from the Mediterranean margin of Gondwana, with only two spe- cies of Horderleyella Bancroft, 1928 (Havlíček 1977) from the lower Katian of Bohemia, another one from the Hirnantian of Morocco (Havlíček 1971), and a species of Reuschella Bancroft, 1928, from the upper Sandbian of the Iberian Chains (Villas 1992). According to Villas (1992), the record of an undetermined species of Reuschella, by Havlíček et al. (1987) in the Katian of Sardinia actually corresponds to the orthoid Multicostella schoenlaubi Havlíček \& Kř́ž (in Havlíček et al. 1987). The recent taxonomic study of the rhynchonelliformean brachiopods from the Darriwilian dark shales of the Central Iberian Zone, Central Spain (Reyes-Abril 2009, Reyes-Abril et al. 2010), 


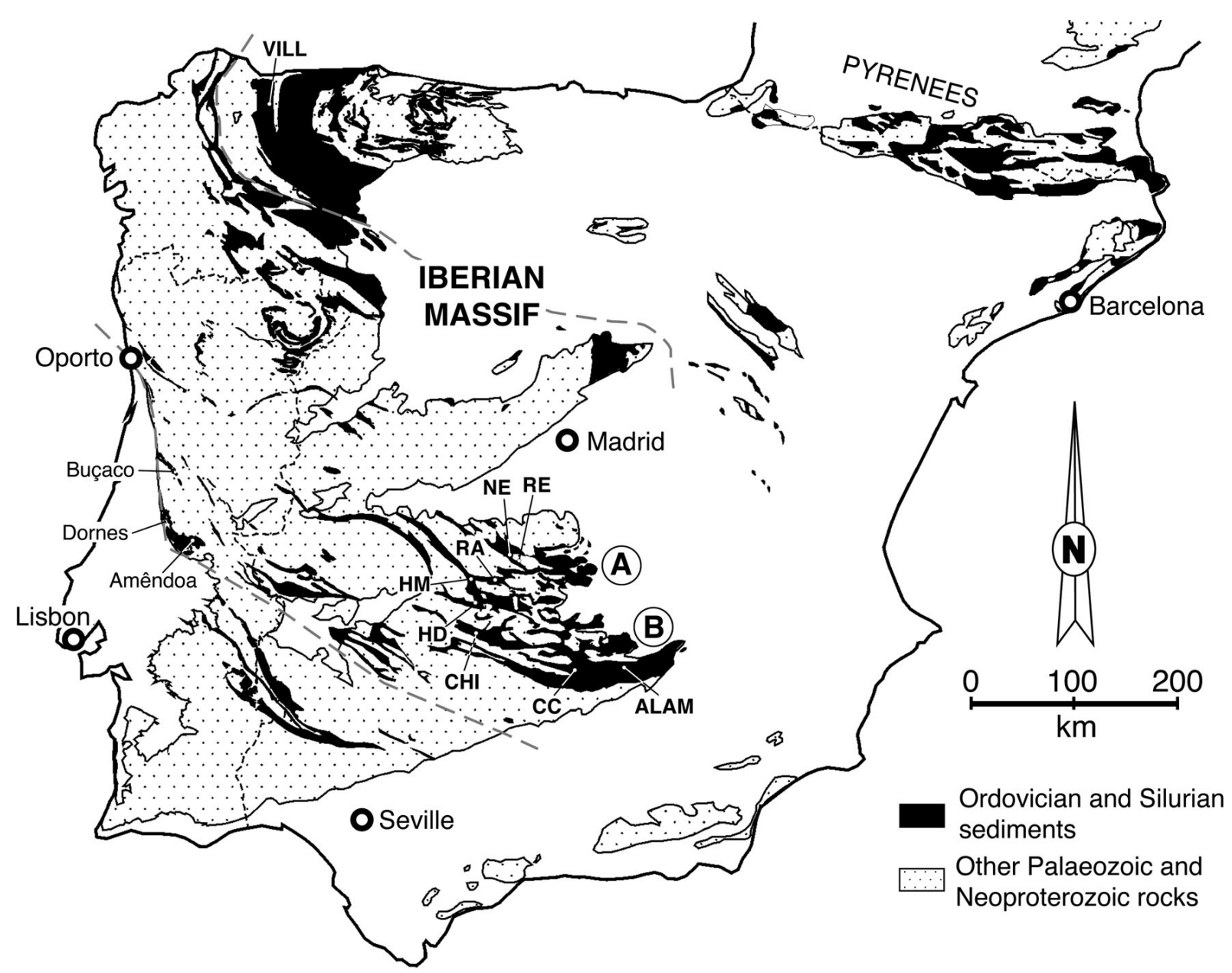

Figure 1. Simplified geological map with the main Ordovician-Silurian outcrops of the Iberian Peninsula, with approximate position of the brachiopod localities cited in the text, including the Portuguese localities with confirmed occurrences of Cacemia ribeiroi: Buçaco (Ribeiro et al. 1853, Delgado 1908, Mitchell 1974), Dornes (Cooper 1980) and Amêndoa-Mação (Delgado 1908, Romão 2000). Abbreviations of selected localities: ALAM - La Alameda; CHI - northwest of Chillón (for material in Born 1918); CC - Calzada de Calatrava; HD - Herrera del Duque; HM - Helechosa de los Montes; NE - Navas de Estena; RA - Los Rasos (Horcajo de los Montes); RE - Retuerta del Bullaque; VILL - Villaodrid-San Mamede (material in Gutiérrez-Marco et al. 1999). For precise coordinates see the text. A, B are the representative areas of lithostratigraphic sections detailed in Fig. 2.

allows the addition of a new genus, Isabelella Reyes-Abril \& Villas gen. nov., to this reduced list, as well as the possible assignment of the genus Cacemia Mitchell, 1974, which was previously included within the family Heterorthidae Schuchert \& Cooper, 1931, to the Harknessellidae.

To test the inclusion of Isabelella and Cacemia within the family Harknessellidae, we have performed a phylogenetic analysis, including in our data matrix these two genera, plus those included by Harper (2000 and 2007) in the families Harknessellidae and Heterorthidae, and defining the primitive dalmanelloid Paurorthis Schuchert \& Cooper, 1931 as an outgroup. Considering the relatively early stratigraphic record of the two Iberian genera within the family Harknessellidae, we also aim to trace their place in the family's evolutionary tree with this phylogenetic analysis.

\section{Geographical and geological setting}

The material studied comes from several localities in the southern part of the Central Iberian Zone of the Iberian Massif. It was collected primarily by Gutiérrez-Marco et al. (1984), and subsequently increased by a new sampling for the present study. The sections examined are located within the middle portion of the Ordovician succession overlying the ubiquitous Armorican Quartzite (Lower Ordovician, essentially Floian in age). The Middle Ordovician rocks are composed predominantly of dark shales and siltstones with variably significant sandstone intercalations known as "Tristani Beds" or "Neseuretus Shales and Sandstones" (Hammann et al. 1982, Gutiérrez-Marco et al. 1994). A map of the main Ordovician outcrops of the Iberian Massif with the location of the fossiliferous localities studied herein is shown in Fig. 1. 
Toledo Mountains

-Villuercas
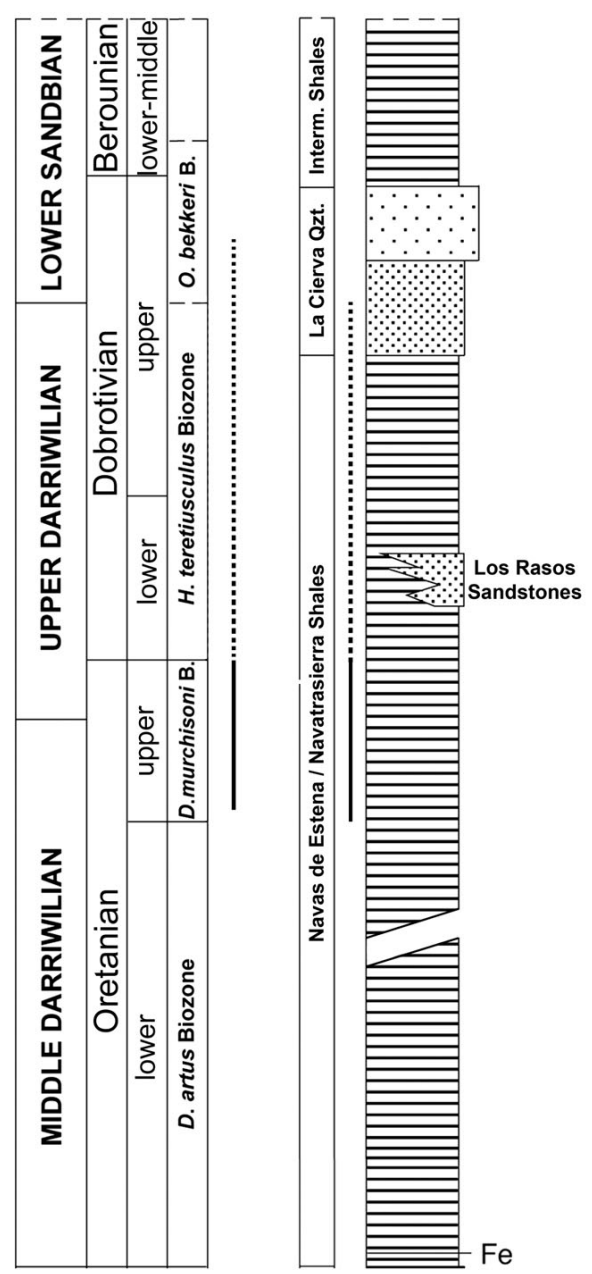

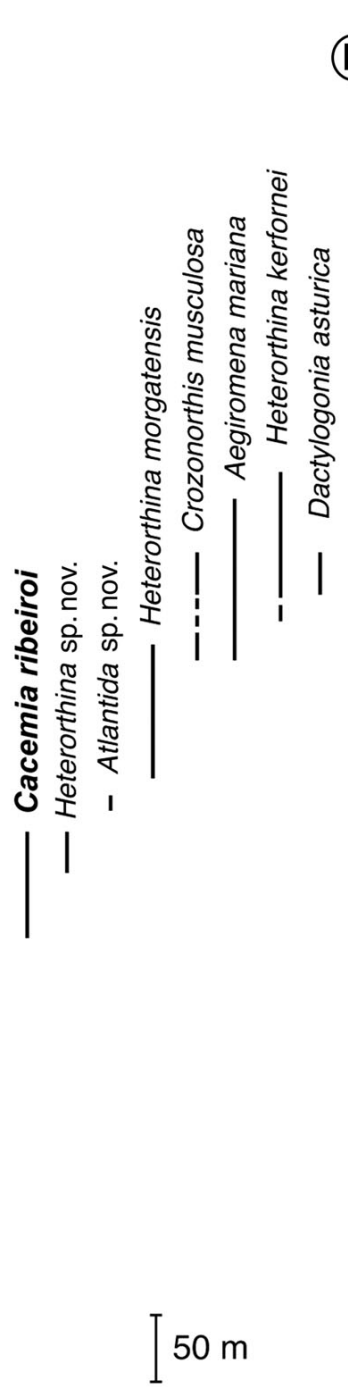

(B) Almadén-Eastern
Sierra Morena

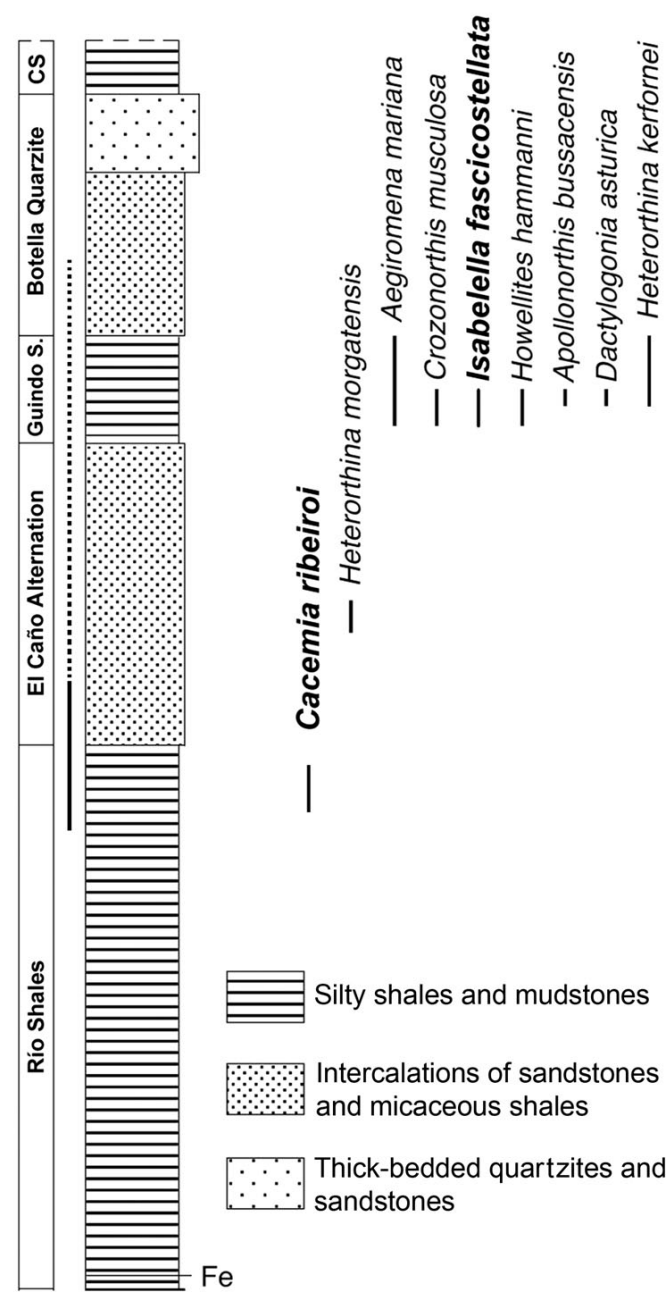

Figure 2. Generalised stratigraphic columns of the Middle Ordovician succession in the southern Central-Iberian Zone, representative of the two main areas (A and B) indicated in Fig. 1. They show the vertical distribution of the studied brachiopod taxa and other species occurring in association. The left-hand column presents the equivalence between the global chronostratigraphy and the Mediterranean regional scheme. Abbreviations: B - biozone; CS - Cantera Shales; Fe - oolitic ironstone; Interm. - Intermediate; S - Shales. Note that the stratigraphic ranges of the two graptolite biozones for the studied interval are directly annotated on the left side of each column.

One of the species studied, Cacemia ribeiroi (Sharpe in Ribeiro et al., 1853), is widely distributed throughout the entire Ibero-Armorican area. Its vertical range has been proposed to characterise a homonymous brachiopod biozone since the times of Delgado $(1897,1908)$ and Born (1918), which was later redefined (Gutiérrez-Marco et al. 1984, 2002; Reyes-Abril et al. 2011) and corresponds to the upper Oretanian of the Mediterranean regional scale (= upper middle Darriwilian of the global scale: Bergström et al. 2009).

The only other brachiopod found to occur in the same localities and within the upper range of distribution of C. ribeiroi is a new species of Heterorthina. Cacemia ribeiroi co-occurs in Spanish localities with abundant trilobites of the genera Neseuretus, Salterocoryphe, Colpocoryphe, Eodalmanitina, Ectillaenus, Isabelinia?, Nobilia- saphus, Uralichas, Eccoptochile and Selenopeltis (Rábano 1989), as well as bivalves of the genera Coxiconchia, Praenucula, "Glyptarca" - now Hemiprionodonta - and Redonia (Babin \& Gutiérrez-Marco 1991) and scarce gastropods and rostroconchs. The range of $C$. ribeiroi is bracketed by the record of the graptolite Didymograptus (D.) murchisoni (Beck in Murchison), which occurs in shales directly below and above its first and last appearance.

Isabelella fascicostellata gen. et sp. nov., the other studied species, is more restricted geographically, being known from the eastern Sierra Morena in the basal beds of the Heterorthina kerfornei-Aegiromena mariana brachiopod Biozone (Reyes-Abril et al. 2011). These beds correspond to the upper lower Dobrotivian of the Mediterranean scale (middle upper Darriwilian in global terms) (Fig. 2). 
Isabelella fascicostellata usually occurs beside the typical Mediterranean brachiopods Aegiromena mariana Drot, Dactylogonia asturica (Villas), Howellites hammanni Villas, Heterorthina kerfornei Mélou and Apollonorthis bussacensis (Sharpe).

\section{Systematic palaeontology}

(by Jaime Reyes-Abril \& Enrique Villas)

Repository. - All the specimens are deposited in the $\mathrm{Mu}-$ seo Geominero, Madrid, Spain (MGM-6329-O to MGM-6524-O).

Order Orthida Schuchert \& Cooper, 1932

Suborder Dalmanellidina Moore, 1952

Superfamily Dalmanelloidea Schuchert, 1913

Family Harknessellidae Bancroft, 1928

\section{Genus Isabelella Reyes-Abril \& Villas gen. nov.}

Type species. - Isabelella fascicostellata Reyes-Abril \& Villas gen. et sp. nov., upper Darriwilian (Middle Ordovician), Calzada de Calatrava, Ciudad Real (Spain).

Derivation of name. - In memory of Isabel Reyes Abril, sister of the first author.

Diagnosis. - Shell convexoplane to slightly convexoconcave, of subquadrate outline, weakly unisulcate, with fascicostellate radial ornamentation, posterolateral ribs recurved to intersect posterior margin of valves, flabellate ventral muscle scar, rudimentary notothyrial platform excavated anteriorly by adductor pits, cardinal process differentiated into lobate myophore and short shaft, brachiophore bases converging onto middle ridge and attached to fulcral plates.

Remarks. - This new dalmanellidine genus agrees with the family Harknessellidae Bancroft, 1928 in the subquadrate shell outline of its shell, the angular ribs, the rudimentary notothyrial platform, the lobate myophore and shaft, as well as in the presence of fulcral plates. The main distinguishing feature of the new genus within the family is its convexoplane to convexoconcave profile. Its fascicostellate ornamentation, in addition to the incurvation of the posterolateral ribs to intersect the posterior margin of the valves, also discriminate it from the other harknessellids, although these features could could prove to be only of specific value, if other species are added to what is presently a monospecific genus.

Because of its strongly fascicostellate ornamentation and the obtuse cardinal angles, the new genus is similar to Horderleyella Bancroft, 1928. However, its convexoplane to convexoconcave shell profile is different from the dorsibiconvex one of Horderleyella. Its bilobed to flabellate ventral muscle field is also different from the suboval to rhomboidal one of Horderleyella. Wulongella Zhu, 1985 is the only other genus included within the harknessellids (Harper 2000) that is similar to the new genus in having a convexoconcave profile, although it is very different in many other respects, especially its rectimarginate anterior commissure, very high ventral interarea, widely divergent brachiophores, and the subperipheral rims present in both valve interiors. Actually, the taxonomic affiliation of Wulongella is poorly constrained. According to Popov (written communication, April $28^{\text {th }}$ of 2013) “...the ventral muscle field and mantle canals of Wulongella are markedly different from those in other harknessellid genera, cardinalia with widely divergent socket plates is billingsellide-like and has no analogy in the dalmanellidines and dorsal adductor scars in Wulongella are radially arranged, but not quadripartite as in orthides. All these differences are good enough to put in doubt current assignation of Wulongella to Orthida. More likely it represent an aberrant member of the Polytoechiidae and probably a last billingsellide survivor."

\author{
Isabelella fascicostellata Reyes-Abril \& Villas \\ gen. et sp. nov. \\ Figures 3, 4
}

Derivation of name. - Name refers to its fascicostellate radial ornamentation.

Diagnosis. - As for the genus.

Type specimens. - Holotype: internal mould of ventral valve (MGM-6479-O); paratypes: internal and external moulds of ventral and dorsal valves (MGM-6473-O to MGM-6504-O, MGM-6505-O to MGM-6524-O).

Figure 3. Isabelella fascicostellata Reyes-Abril \& Villas gen. et sp. nov., locality Calzada de Calatrava (CC-I). Scale bars 5 mm. $\bullet$ A, B - internal mould (A) and latex cast of interior (B) of ventral valve, MGM-6477-O. • C - latex cast of exterior of ventral valve, MGM-6486-O. • D, E - internal mould (D) and latex cast of interior (E) of ventral valve, MGM-6484-O. $\bullet$ F - latex cast of exterior of ventral valve, MGM-6487-O. $\bullet$ G, H - internal mould (G) and latex cast of interior $(\mathrm{H})$ of ventral valve, MGM-6479-O. • I - latex cast of exterior of ventral valve, MGM-6476-O. • J, K - internal mould (J) and latex cast of interior (K) of ventral valve, MGM-6488-O. $\bullet$ L - latex cast of exterior of ventral valve, MGM-6496-O. $\bullet$ M - internal mould of ventral valve, MGM-6485-O. • N - latex cast of exterior of ventral valve, MGM-6475-O. • O - latex cast of exterior of dorsal valve, MGM-6495-O. 

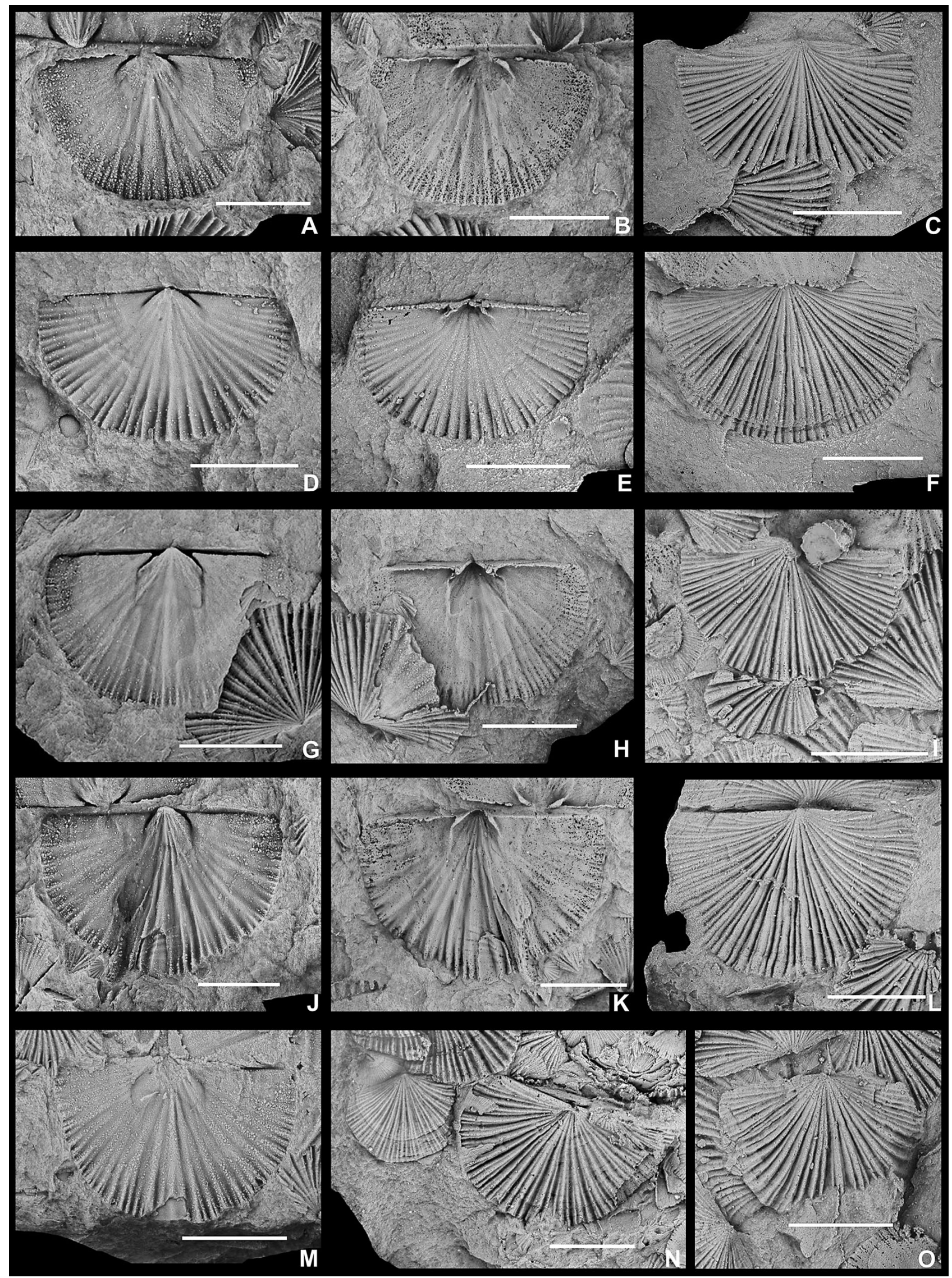
Type horizon. - Guindo Shales (20 $\mathrm{m}$ above its base). Hustedograptus teretiusculus Biozone, upper lower Dobrotivian, upper Darriwilian (Middle Ordovician).

Type locality. - At the base of the Fresneda reservoir dam, $12 \mathrm{~km}$ SE from Calzada de Calatrava, Ciudad Real, Spain (Latitude $38^{\circ} 37^{\prime} 02^{\prime \prime} \mathrm{N}$, Longitude $3^{\circ} 40^{\prime} 52^{\prime \prime} \mathrm{W}$ ).

Description. - Shell convexoplane to convexoconcave, up to $13 \mathrm{~mm}$ long, of subquadrate outline, maximum width immediately anterior to hinge line, cardinal angles rounded and slightly obtuse, $56-74 \%$ as long as wide (mean [m] = 0.65 , variance $[\mathrm{v}]=0.004$, number $[\mathrm{n}]=31$ ), with slightly sulcate anterior commissure. Ventral valve planar to weakly concave, slightly carinate; ventral interarea apsacline, very short, approximately $5 \%$ as long as valve, with wide, open delthyrium. Dorsal valve convex, approximately $20 \%$ as deep as long, with narrow and shallow sulcus occupied by interior costellae of first rib sectors; dorsal interarea nearly as long as ventral interarea, anacline, with open notothyrium. Radial ornament strongly fascicostellate, with up to three generations of costellae, posterolateral ribs slightly incurved to cut posterior margin of valves; ribs high, subtriangular in section, numbering 10 to 14 per $5 \mathrm{~mm}$ at $5 \mathrm{~mm}$ anteromedially from umbo; filate, with up to four marked growth striae in largest shells.

Ventral valve with small deltidiodont teeth, curved and short dental plates, strongly divergent anteriorly and continuous with very weak muscle bounding ridges, only more accentuated laterally in largest valves. Ventral muscle field flabellate, with diductor scars diverging anteriorly, wider and longer than adductor scars, not enclosing them anteriorly, $26-42 \%$ as long as valve $(\mathrm{m}=0.35, \mathrm{v}=0.01, \mathrm{n}=14)$, $19-33 \%$ as wide as valve $(\mathrm{m}=0.26, \mathrm{v}=0.002, \mathrm{n}=16)$. Vascula media slightly diverging from anterior ends of diductor scars, digitating at $3 / 4$ valve length.

Dorsal valve with short poorly developed nothothyrial platform, excavated anteriorly by posterior ends of adductor scars, forming adductor pits. Cardinal process with bilobed myophore and short shaft, continuous anteriorly with strong and high median ridge, extending anteriorly to mid-valve of largest shells. Brachiophores bladelike, short, converging onto median ridge, welded to fulcral plates. Dorsal muscle field poorly visible due to strong internal impression of ribbing, with both anterior and posterior adductors halved by curved transverse ridges (Fig. 4G, H).
Radial ornament strongly impressed on valve interiors, with dense endopunctation, especially on valve margins.

Stratigraphic and geographic range. - Southern Central Iberian Zone: lower part of the Guindo Shales at Calzada de Calatrava (Ciudad Real) in beds of late early Dobrotivian age (middle late Darriwilian), within the Hustedograptus teretiusculus graptolite Biozone, as well as in the lower part of the Heterorthina kerfornei-Aegiromena mariana brachiopod Biozone. In addition to the type locality, the species also occurs in the same unit and stratigraphic position about $46 \mathrm{~km}$ southeast of the Fresneda reservoir, in the northern flank of the Eastern Sierra Morena antiform. This second fossil locality lies in the La Alameda area, $13.5 \mathrm{~km}$ east of Aldeaquemada (locality ALAM-II, Latitude $38^{\circ}$ $25^{\prime} 47^{\prime \prime} \mathrm{N}$, Longitude $3^{\circ} 12^{\prime} 59^{\prime \prime} \mathrm{W}$ ).

\section{Genus Cacemia Mitchell, 1974}

Type species. - Orthis ribeiroi Sharpe (in Ribeiro et al., 1853). Late middle Darriwilian, Buçaco, Portugal.

Emended diagnosis. - Shell concavoconvex, subrectangular in young stages to strongly mucronate in adults, with sulcate anterior commissure and posterolateral ribs parallel to hinge line. Ventral interior with divergent dental plates, muscle field quadrate to flabellate extending forward beyond the delthyrial cavity. Dorsal interior with cardinal process differentiated into bilobed myophore and medially cleft shaft, and widely divergent brachiophores.

Remarks. - The original classification of the genus Cacemia to the heterorthids by Mitchell (1974) was surely influenced by the assignment to the genus of not only the type species Orthis ribeiroi Sharpe (in Ribeiro et al., 1853) but also a second Portuguese brachiopod species from the type area of $C$. ribeiroi, represented by a single dorsal valve identified by Mitchell (1974) as Cacemia sp. nov. This latter specimen certainly belongs to a heterorthid, but displays important differences with C. ribeiroi to be considered congeneric with it. In fact, the obtuse and rounded cardinal angles of that dorsal valve, and the strongly convergent brachiophore bases onto the notothyrial platform, are typical features of the heterorthid Tissintia Havlíček, 1970. This assignment was also suggested to

Figure 4. Isabelella fascicostellata Reyes-Abril \& Villas gen. et sp. nov., locality Calzada de Calatrava (CC-I). Scale bars 5 mm. $\bullet$ A, B - internal mould (A) and latex cast of interior (B) of dorsal valve, MGM-6511-O. $\bullet$ C - internal mould of dorsal valve, MGM-6512-O. • D, E-internal mould (D) and latex cast of interior (E) of dorsal valve, MGM-6507-O. • F - latex cast of exterior of dorsal valve, MGM-6506-O. • G, H - internal mould (G) and latex cast of interior $(\mathrm{H})$ of dorsal valve, MGM-6514-O. $\bullet$ I - latex cast of exterior of dorsal valve, MGM-6510-O. $\bullet \mathrm{J}, \mathrm{K}-$ internal mould $(\mathrm{J})$ and latex cast of interior $(\mathrm{K})$ of dorsal valve, MGM-6508-O. $\bullet$ L - latex cast of exterior of dorsal valve, MGM-6516-O. $\bullet$ M, N - internal mould (M) and latex cast of interior $(\mathrm{N})$ of dorsal valve, MGM-6515-O. • O - latex cast of exterior of dorsal valve, MGM-6520-O. 


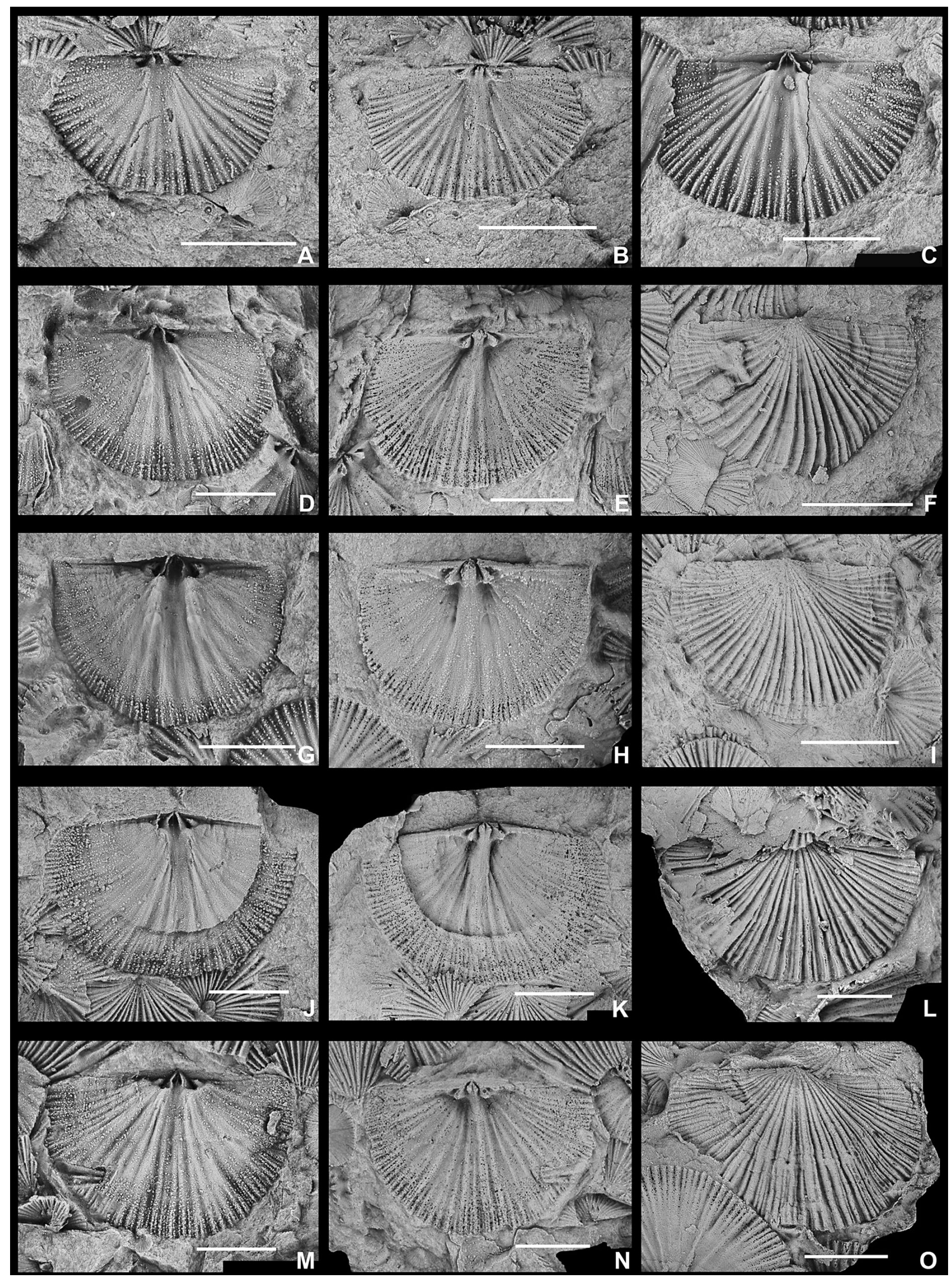


one of the authors (E. V.) by Mitchell (written communication 1980).

Cacemia ribeiroi was also considered to be a heterorthid by Mélou (1976) in his study of a collection from the Armorican Massif. Nevertheless, Havlíček (1977) rejected Cacemia from the family Heterorthidae. Certainly, the genus is very different from his main criteria on the family identity (Havlíček 1970). The strongly mucronate outline of the adult valves of Cacemia is completely unknown within the family Heterorthidae, its sulcate anterior commissure also does not fit among the typically rectimarginate heterorthid shells, and its ribs never curve posterolaterally to intersect the hinge line, as is usual within the family.

Harper (2000) retained Cacemia within the family Heterorthidae, illustrating the same dorsal valve of Tissintia identified by Mitchell (1974, pl. 1, figs 5 and 6) as Cacemia sp. nov. as representative of the genus.

Our study of a large collection of Cacemia ribeiroi from the late middle Darriwilian of Central Iberia allows us to reject the inclusion of the genus in the heterorthids because of the important differences stated above and because of a misidentification of a part of the collection considered by Mitchell (1974) in designating the genus. We have also compared Cacemia with genera of the family Harknessellidae, considering the peculiar mucronate outline of its adult shells. Within the dalmanelloids this feature is only known from some harknessellids. The cladistic analysis below places Cacemia as a basal taxon within the harknessellid clade, very close to Isabelella.

\section{Cacemia ribeiroi (Sharpe in Ribeiro et al., 1853)}

Figures 5, 6

1853 Orthis Ribeiro, n. s. Sharpe in Ribeiro et al., pp. 152-153, pl. 8, figs 1a-d.

1855 Orthis vespertilio Sow. - Verneuil \& Barrande, p. 992 , pl. 27, fig. 8 .

1918 Orthis Ribeiroi Sharpe. - Born, pp. 335-336, pl. 24, fig. 1a-d.

1974 Cacemia ribeiroi (Sharpe). - Mitchell, p. 394, pl. 1, figs 1-6.

1976 Cacemia ribeiroi (Sharpe). - Mélou, pp. 698-700, pl. 3, figs 1-15.

1998 Cacemia ribeiroi (Sharpe). - Mélou \& Pillet, p. 92, figs 1,2 . cf. 1999 Cacemia cf. ribeiroi (Sharpe). - Mélou, Oulebsir \& Paris, p. 832, figs 3.1, 3.2.

1999 Cacemia ribeiroi (Sharpe). - Gutiérrez-Marco in Gutiérrez-Marco et al., pp. 54-55, pl. 4, figs 1-3.

2011 Cacemia ribeiroi (Sharpe). - Reyes-Abril, Gutiérrez-Marco \& Villas, pl. 1, fig. M.

Lectotype. - External and internal mould of a ventral valve (B 82982) figured by Sharpe (in Ribeiro, 1853, pl. 8, fig. 1a, b) and selected by Mitchell (1974). Specimens stored in the Natural History Museum of London, under catalogue number B 82982.

Diagnosis. - As for the genus.

Spanish material. - Internal and external moulds of over one hundred ventral and dorsal valves, preserved in shales and silty nodules, among which we have selected 94 specimens (MGM-6329-O to MGM-6423-O).

Description. - Shell concavoconvex, up to $22 \mathrm{~mm}$ long, with subquadrate outline in young stages and strongly mucronate in adults. Maximum width along hinge line, rectangular cardinal angles in young stages and extremely acute in adults, length to width ratio strongly variable with age due to heterometric growth, 30-80\% as long as wide, lowest values corresponding to largest shells. Anterior commissure strongly sulcate. Ventral valve convex with strong median fold, $21-32 \%$ as deep as long $(\mathrm{m}=0.26, \mathrm{v}=$ $0.002, \mathrm{n}=13$ ); ventral interarea apsacline, 5-9\% as long as valve, with open delthyrium. Dorsal valve concave, with accentuated median sulcus; dorsal interarea anacline, $4-8 \%$ as long as valve $(\mathrm{m}=0.6, \mathrm{v}=0.0003, \mathrm{n}=20)$, with open notothyrium. Radial ornament fascicostellate, with 13-15 ribs in $5 \mathrm{~mm}$ at $5 \mathrm{~mm}$ anteromedially from umbo; up to three marked growth striae in adult valves.

Ventral valve interior with pedicle callist, triangular teeth and divergent dental plates, continuous anteriorly with muscle bounding ridges. Muscle field subquadrate in young stages and flabellate in adults, with scalloped lateral margins, $30-75 \%$ as long as valve $(\mathrm{m}=0.51, \mathrm{v}=0.01, \mathrm{n}=$ $53), 15-40 \%$ as wide as valve $(m=0.26, v=0.003, n=65)$, diductor scars much larger than adductor scars, enclosing them anteriorly.

Dorsal valve interior with short and wide notothyrial platform, continuous with robust median ridge, reaching

Figure 5. Cacemia ribeiroi (Sharpe in Ribeiro et al., 1853), localities Herrera del Duque (HD-V, HD-VII), Helechosa de los Montes (HM-IV), Rasos (RA-I) and Retuerta del Bullaque (RE-V). Scale bars $5 \mathrm{~mm}$. • A - internal mould of ventral valve, MGM-6342-O (HD-V). B - latex cast of exterior of ventral valve, MGM-6354-O (RE-V). $\bullet$ C - internal mould of ventral valve, MGM-6335-O (RA-I). D - internal mould of ventral valve, MGM-6400-O (RE-V). $\bullet$ E - internal mould of ventral valve, MGM-6335-O, (RA-I). $\bullet \mathrm{F}, \mathrm{G}-$ internal mould (F) and latex cast of exterior (G) of ventral valve, MGM-6367-O (HD-VII). • H - internal mould of ventral valve, MGM-6344-O (HD-V). • I - latex cast of exterior of ventral valve, MGM-6346-O $(\mathrm{HM}-\mathrm{IV}) \cdot \bullet \mathrm{J}, \mathrm{K}-$ internal mould $(\mathrm{J})$ and latex cast of exterior (K) of ventral valve, MGM-6341-O (HM-IV). 

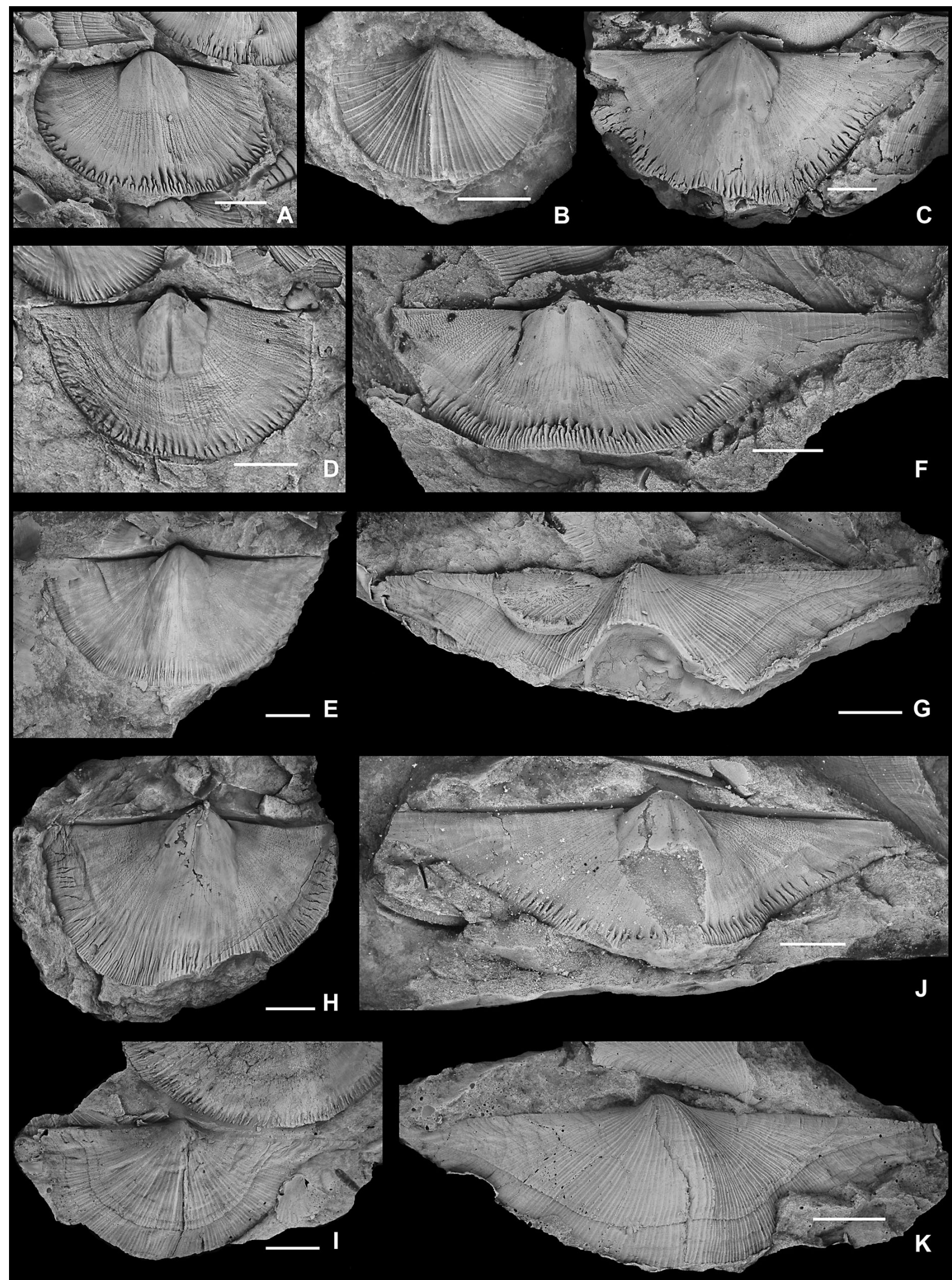
two thirds valve length. Cardinal process differentiated into bilobed myophore, filling notothyrium completely in adults, and wide and short medially cleft shaft. Brachiophores diverging anteriorly, with bases converging onto notothyrial platform and welded to rudimentary fulcral plates. Dorsal muscle field quadripartite, with rectangular posterior adductor scars, larger than triangular anterior scars, separated by transverse ridges that diverge anteriorly.

Radial ornamentation slightly impressed on valve interiors, with tiny tubercles radially arranged, about six per $\mathrm{mm}$, surrounding muscle fields of both valves; if related to vascula genitalia they would characterise a lemniscate mantle canal system, without traces of vascula media; bifurcating ends of mantle canals, projecting from areas covered with tiny tubercles, strongly impressed on valve margins. No trace of perforation infilling on internal moulds suggesting endopunctate shell structure.

Remarks. - There are no significant differences with the species descriptions from Portugal (Mitchell 1974) and those from the Armorican Massif (Mélou 1976), although there is an important difference with the interpretation made by these authors of the radially arranged tubercles on both valve interiors. Mitchell (1974), when describing the shell substance as finely and densely punctate, was most likely referring to the tiny tubercles, relating them to endopunctation. Mélou (1976) described the tubercles more extensively, comparing their arrangement with the punctation of Heterorthina and other heterorthids, and concluding that tubercles and punctae were related. Certainly, the tubercles' radial arrangement, following the ribbing's internal impressions, is reminiscent of the arrangement of the endopunctae, although they do not display any trace of perforations penetrating the shell. Because of their arrangement and size, the tubercles are reminiscent of rows of sediment infilling of the endopunctae on the internal moulds, with the important difference that they occur as rounded depressions on these moulds. Another difference is that the area of occurrence of these structures on the valve interiors surrounds the muscle fields and not the valve margins, where the bifurcating ends of the mantle canals replace the structures. The endopunctae are usually much better developed on the valve margins, especially in adult shells; see, for example, the valve interiors of Isabelella fascicostellata, described above. In contrast, the tiny protuberances of Cacemia ribeiroi are only developed on the central and po- sterolateral areas, surrounding the muscle field, a region that is usually occupied by the gonad impressions. In addition, the gonad impressions are usually accompanied by relatively accentuated and relatively regularly arranged tuberculation, as found on the ventral valves of Crozonorthis musculosa Mélou, 1974, and on both valve interiors of Apollonorthis bussacensis (Sharpe in Ribeiro et al., 1853), see Mélou (1974, pls 1, 2, 4 and 5).

Further studies of preserved calcite shells are needed to test these interpretations of the internal tuberculation and to determine the shell structure.

Geographic and stratigraphic range. - In the 75 years following the initial characterisation of $C$. ribeiroi in Portugal (Sharpe in Ribeiro et al. 1853), the species was recognized in a number of localities of Britain, Normandy and Spain, including the Iberian Cordillera and the Cantabrian and Central-Iberian zones of the Iberian Massif. However, many of these early records from France and Spain were mistaken with different species of brachiopods of "alate" appearance, coming either from older beds (i.e., Paralenorthis spp.) or from Upper Ordovician strata, such as the locality "Renazé" of Tromelin \& Lebesconte (1876) and the record of a "different variety" of Orthis Ribeiroi in the Louredo Formation of Buçaco (Delgado 1908). Cacemia ribeiroi is unquestionably present in upper Oretanian (= upper middle Darriwilian) shales of the Central-Iberian Zone: upper half of the Brejo Fundeiro Formation of the Buçaco, Dornes and Amêndoa areas, Portugal; lower part of the Navas de Estena and Navatrasierra formations, and upper part of the Rio Formation in Spain. Also it was found in the middle part of the Luarca Formation of the West AsturianLeonese Zone (northwestern Spain: Gutiérrez-Marco et al. 1999). In the Armorican Massif (France), the species has been described from the lower part of the Postolonnec Formation (Mélou 1976) and the Angers Formation (Mélou \& Pillet 1998). The distribution of $C$. ribeiroi probably extends to north Africa, where several external moulds of valves described as $C$. cf. ribeiroi have been recorded in upper Oretanian beds from the Hassi Touareg Formation of the northeast of the Algerian Sahara (Mélou et al. 1999).

The Spanish material illustrated here comes from selected fossil localities in the Central-Iberian Zone (Fig. 1), where $C$. ribeiroi is especially abundant and shows good preservation. From north to south, the first two (of seven) fossil localities lie in the Navas de Estena syncline, $5.5 \mathrm{~km}$

Figure 6. Cacemia ribeiroi (Sharpe in Ribeiro et al., 1853), localities Navas de Estena (NE-VI), Herrera del Duque (HD-V), Los Rasos (RA-I) and Retuerta del Bullaque (RE-V). Scale bars $5 \mathrm{~mm}$. $-\mathrm{A}-\mathrm{C}$ - internal mould (A), latex cast of interior (B) and latex cast of exterior (C) of dorsal valve, MGM-6437-O (NE-VI). • D, E - internal mould (D) and latex cast of interior (E) of dorsal valve, MGM-6414-O (HD-V). • F, G - internal mould (F) and latex cast of interior (G) of dorsal valve, MGM-6471-O (NE-VI). $\bullet$ H, I - internal mould (H) and latex cast of exterior (I) of dorsal valve, MGM-6435-O (RA-I). $\bullet \mathrm{J}-$ latex cast of exterior of dorsal valve MGM-6443-O, (RA-I). $\bullet \mathrm{K}-$ internal mould of dorsal valve, MGM-6417-O (RE-V). $\bullet$ L - latex cast of exterior of dorsal valve, MGM-6431-O (NE-VI). 


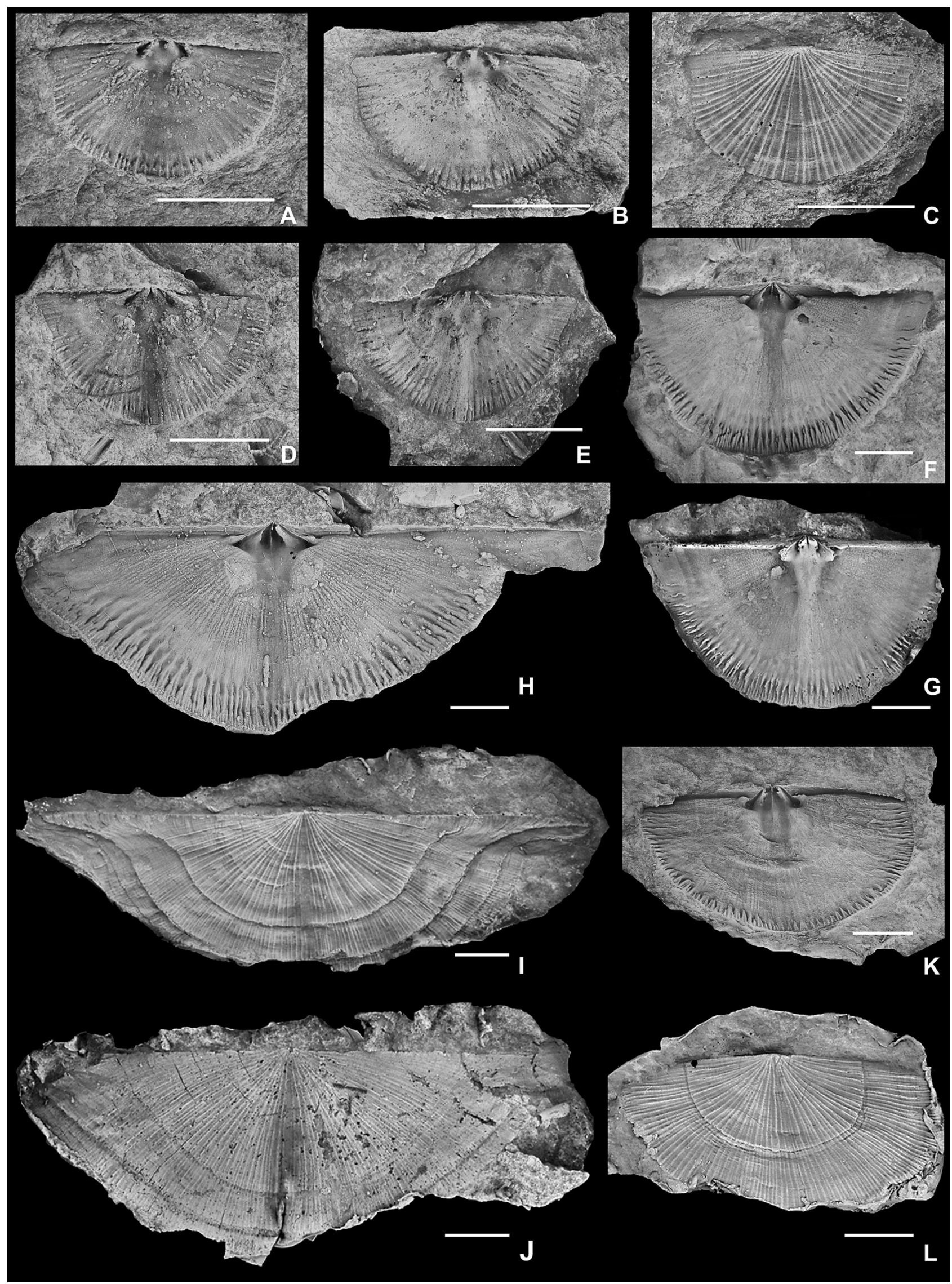


Table 1. Codification of the 22 characters used in the cladistic analysis. The character numbers coincide with those used in the development of the classification of the order Orthida by Williams \& Harper (2000), with the adding of four new characters (43 to 46) commented in the text below.

\begin{tabular}{|c|c|c|c|c|c|c|c|c|c|c|c|c|c|c|c|c|c|c|c|c|c|c|}
\hline $\begin{array}{ll} & \text { Character } \\
\text { Genus } & \end{array}$ & 4 & 5 & 7 & 8 & 9 & 16 & 18 & 19 & 21 & 24 & 25 & 27 & 29 & 30 & 32 & 35 & 36 & 40 & 43 & 44 & 45 & 46 \\
\hline Paurorthis & 0 & 1 & 2 & 1 & 4 & 0 & 0 & 2 & 2 & 1 & 3 & 3 & 0 & 1 & 6 & 3 & 2 & 0 & 0 & 0 & 1 & 1 \\
\hline Cacemia & 1 & 3 & 4 & 1 & $4 \& 5$ & 1 & 0 & 4 & 4 & 5 & 3 & 5 & 0 & 5 & 1 & 2 & 2 & 0 & 2 & 1 & 0 & 0 \\
\hline Harknessella & 1 & $2 \& 3$ & 0 & 1 & 4 & 0 & 0 & 4 & 4 & 5 & 3 & 4 & 1 & 2 & 1 & 0 & 0 & 0 & 2 & 1 & 0 & 1 \\
\hline Haymina & 1 & 1 & 1 & 2 & 5 & 0 & 0 & 4 & 4 & 5 & 1 & $?$ & $?$ & 2 & 1 & $?$ & 0 & 0 & 0 & 0 & $?$ & $?$ \\
\hline Horderleyella & 1 & 1 & 1 & 1 & 4 & 0 & 0 & 4 & 4 & 5 & 3 & 4 & 1 & 1 & 1 & $?$ & 0 & 0 & 2 & 1 & 0 & 1 \\
\hline Isabelella & 1 & 1 & 5 & 1 & 4 & 0 & 0 & 4 & 4 & 5 & 3 & 4 & 1 & 5 & 1 & 1 & 0 & 0 & 2 & 1 & 1 & 1 \\
\hline Kampella & 0 & 1 & 0 & 1 & 4 & 0 & 0 & $?$ & 4 & 5 & 4 & 5 & 1 & 2 & 1 & 3 & 0 & 0 & 2 & 0 & 1 & 0 \\
\hline Reuschella & 1 & $2 \& 3$ & 1 & 1 & 2 & 0 & 0 & 4 & 4 & 5 & 3 & 5 & 1 & 2 & 1 & 1 & 0 & 0 & 2 & 1 & 0 & 1 \\
\hline Smeathenella & 1 & 2 & 1 & 1 & 5 & 0 & 0 & 4 & 4 & 5 & 3 & 4 & 0 & 1 & 1 & 0 & 0 & 0 & 0 & 0 & 0 & 1 \\
\hline Heterorthis & 1 & 1 & 3 & 0 & 4 & 1 & 3 & 4 & 4 & 2 & 3 & 3 & 0 & 5 & 1 & 3 & 2 & 1 & 2 & 2 & 1 & 0 \\
\hline Arenorthis & 2 & 1 & 2 & 1 & 4 & 0 & 2 & 4 & 4 & 2 & 0 & 3 & 0 & 5 & 1 & 4 & 2 & 1 & 2 & 2 & 1 & 0 \\
\hline Cilinella & 2 & 1 & 1 & 0 & 4 & 0 & 0 & 4 & 4 & 2 & $?$ & 5 & 0 & 5 & 1 & 2 & 0 & 0 & 2 & $?$ & 1 & 0 \\
\hline Heterorthella & 0 & 1 & 3 & 0 & 5 & 0 & 0 & 4 & 4 & 2 & 3 & 5 & 0 & 5 & 1 & $?$ & 0 & 1 & 2 & 1 & 1 & 0 \\
\hline Heterorthina & 2 & 1 & 3 & 1 & 3 & 1 & 0 & 2 & 4 & 2 & 3 & 3 & 0 & 5 & 1 & 3 & 2 & 0 & 2 & 1 & 1 & 0 \\
\hline Incorthis & 0 & 1 & 0 & 1 & 3 & 0 & 0 & 4 & $?$ & 5 & $?$ & 5 & 0 & 2 & 0 & $?$ & 2 & 0 & 0 & 0 & 1 & 0 \\
\hline Marionites & 2 & 1 & $5 \& 6$ & 1 & 3 & 0 & 0 & 4 & 4 & 2 & 3 & 3 & 0 & 5 & 1 & $?$ & 2 & 0 & 1 & 1 & 1 & 0 \\
\hline Svobodaina & 2 & 1 & 1 & 1 & 4 & 1 & 0 & 4 & 4 & 2 & 3 & 5 & 0 & 5 & 1 & 3 & 2 & 0 & 2 & 3 & 1 & 0 \\
\hline Tafilaltia & 0 & 1 & 2 & 1 & 4 & 1 & 0 & 4 & 4 & 2 & 3 & 3 & 0 & 5 & 1 & 3 & 2 & $?$ & 1 & 2 & 1 & 0 \\
\hline Tissintia & 0 & 1 & 2 & 1 & 4 & 1 & 0 & 4 & 4 & 2 & 3 & 5 & 0 & 5 & 1 & $?$ & 2 & 0 & 2 & 1 & 1 & 0 \\
\hline
\end{tabular}

southeast of the homonymous locality (site NE-VI: Latitude $39^{\circ} 27^{\prime} 49^{\prime \prime} \mathrm{N}$, Longitude $4^{\circ} 28^{\prime} 17^{\prime \prime} \mathrm{W}$ ) and $2 \mathrm{~km}$ south of Retuerta del Bullaque (loc. RE-V: Latitude $39^{\circ}$ $26^{\prime} 37^{\prime \prime} \mathrm{N}$, Longitude $4^{\circ} 23^{\prime} 59^{\prime \prime} \mathrm{W}$ ). The next fossil localities fall in the Guadarranque syncline, $1 \mathrm{~km}$ east of Helechosa de los Montes (HM-IV: Latitude $39^{\circ} 18^{\prime} 42^{\prime \prime} \mathrm{N}$, Longitude $4^{\circ} 53^{\prime} 45^{\prime \prime} \mathrm{W}$ ) and $7.2 \mathrm{~km}$ east of Horcajo de los Montes (RA-I at Los Rasos farm: Latitude $39^{\circ} 18^{\prime} 08^{\prime \prime} \mathrm{N}$, Longitude $\left.4^{\circ} 34^{\prime} 19^{\prime \prime} \mathrm{W}\right)$, respectively. In the Herrera syncline, two localities lie respectively $3.5 \mathrm{~km}$ to the southwest of Herrera del Duque (HD-V: Latitude $39^{\circ} 08^{\prime} 34^{\prime \prime} \mathrm{N}$, Longitude $5^{\circ} 04^{\prime} 30^{\prime \prime} \mathrm{W}$ ) and $4.4 \mathrm{~km}$ east of Fuenlabrada de los Montes (HD-VII: Latitude $39^{\circ} 05^{\prime} 53^{\prime \prime} \mathrm{N}$, Longitude $\left.4^{\circ} 55^{\prime} 05^{\prime \prime} \mathrm{W}\right)$. Cacemia ribeiroi is also known from some localities in the Almadén syncline, such as "Cañadillas" (Born 1918) or "La Ballestera" (Verneuil \& Barrande 1855). The first corresponds to our locality CHI-IV north of Chillón, in the Huerta del Llano area (Latitude $38^{\circ} 51^{\prime} 41^{\prime \prime} \mathrm{N}$, Longitude $3^{\circ} 52^{\prime} 25^{\prime \prime} \mathrm{W}$ ). Abbreviations for brachiopod localities are the same as those used for the trilobite localities in Rábano (1989).

\section{Phylogenetic analysis of the family Harknessellidae}

The family Harknessellidae is one of the 14 families included within the Dalmanelloidea in the revised Treatise (Har- per 2000). It is characterised by a frequently mucronate hinge line, fulcral plates usually present, and a rudimentary notothyrial platform, anteriorly excavated by posterior adductor scars. Variable shell profiles, radial ornamentation and ventral muscle fields allow for ready differentiation between the genera. Four of the five genera originally included by Bancroft (1928) within the group: Harknessella Reed, 1917, Horderleyella Bancroft, 1928, Reuschella Bancroft, 1928 and Smeathenella Bancroft, 1928, currently remain within it, while Marionites Cooper \& Muir-Wood, 1951 (nom. nov. pro Marionella Bancroft, 1928) was included within the heterorthids after its revision by Havlíček (1967). Since the formal designation of the group, initially considered by Bancroft (1928) to be a subfamily within the Rhipidomellidae, only three new genera have provisionally been included within the family (Harper 2000 and 2007). They are Kampella Baarli, 1988, from the Lower Silurian of Norway (initially assigned to the heterorthids); Wulongella Zhu, 1985, from the Upper Ordovician of North China (compared by his author with the Orthoidea Dolerothis and Eostrophomena); and Haymina Bogoyavlenskaya, 1991, from the Middle Ordovician of the northern Urals (originally assigned to the family Paurorthidae Öpik, 1933).

The earliest known genera in the family are Horderleyella and Haymina, from the uppermost Middle Ordovician, but most of its genera are restricted to the Upper Ordovician, with only one possible record from the Lower Silurian (Kampella). The two genera from the Ordovician of 


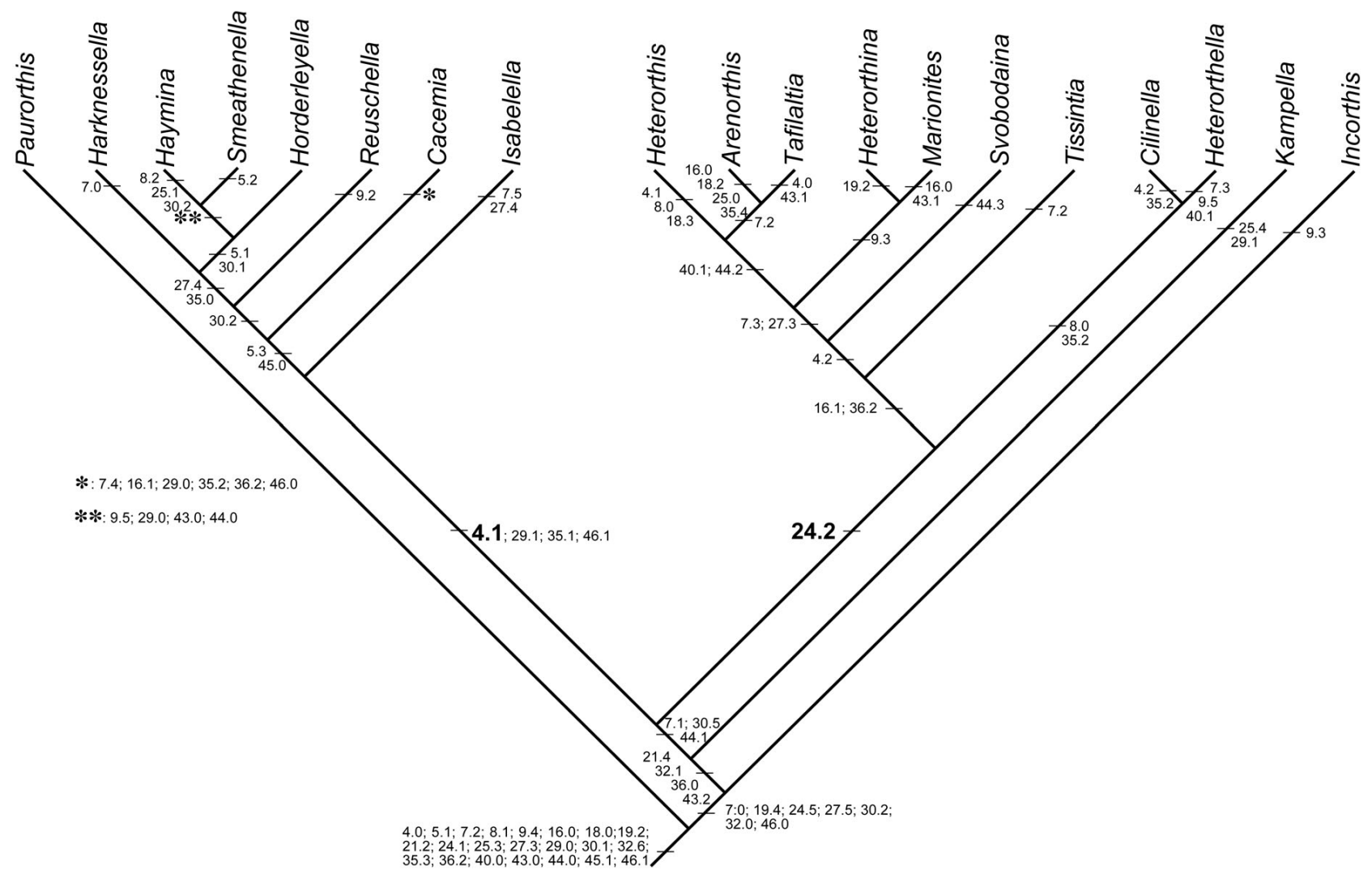

Figure 7. Most parsimonious tree using branch and bound search in the cladistic analysis of the families Harknessellidae and Heterorthidae using Paurorthis as an outgroup and the characters mentioned in the text. Numbers indicate the synapomorphy on each tree branch (character/state) and boldface numbers refer to the main synapomorphy that defines each family.

the Iberian Peninsula, Isabelella and Cacemia, proposed above to be included within the harknessellids, would also fall in the earliest known range of the family.

To analyse the phylogeny of the family, a cladistic analysis has been developed, interrogating a matrix of the eight considered harknessellid genera (excluding Wulongella for the reasons commented in the remarks on Isabelella), together with the 10 genera included within the family Heterorhidae (Harper 2000), as well as Paurorthis as an outgroup. Paurorthis is a relatively simple dalmanelloid genus known from Lower Ordovician rocks. The analysis involved the coding of the same 42 characters and states used in the development of the classification of the order Orthida by Williams \& Harper (2000), although 22 of those characters display the same state in all of the studied genera. Characters 37 and 38, referring to variations in the cardinal process have been replaced by two new characters ( 43 and the 44) which simplifies the analysis, adapting it to the variability within the groups being analysed. Character 43 refers to variations in the cardinal process, distinguishing between undifferentiated ridge-like (0), undifferentiated spheroid (1) and differentiated in shaft and myophore (3). Character 44 refers to shape of cardinal process: unilobate (0), bilobate (1), trilobate (2) and multifid (3). Two new characters have been added to the former list, corresponding to features occurring frequently in the families being analysed. They are character 45 , which states absence (0) or presence (1) of posterolateral incurved ribs which intersect the posterior valve margin; and character 46, indicating absence (0) or presence (1) of adductor pits excavating the anterior margin of the notothyrial platform (see Table 1).

The analysis was performed with PAUP $4.0 \mathrm{~b} 10$ software (Swofford 2002), supplemented by MacClade 4.06 OSX software (Maddison \& Maddison 2003), and has been carried out using the branch and bound and the heuristic search algorithms, weighting the characters according to their consistency index. All characters were unordered during the analyses. Branch and bound search produces a single most parsimonious tree with a tree length of 43.16, a consistency index of 0.66 , a homoplasy index of 0.34 , a retention index of 0.69 and a rescaled consistency index of 0.45 . Heuristic search produces three most parsimonious trees with a tree length of 43.87 , a consistency index of 0.65 , a homoplasy index of 0.35 , a retention index of 0.67 and a rescaled consistency index of 0.44 . The main differences between the two searches lie in the phylogenetic relationships established between the genera belonging to the family Heterorthidae, as in branch and bound search 


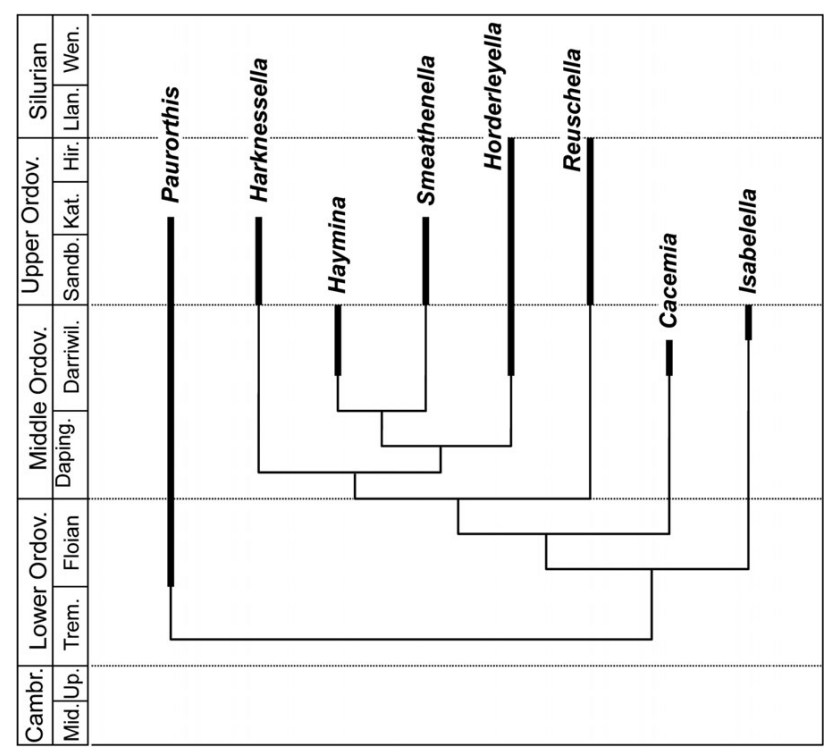

Figure 8. Phylogeny of the Harknessellidae based on the cladistic analysis above.

these genera are grouped in only one subclade while in the heuristic search they form small subclades in the base of the tree. By contrast, the phylogenetic relationships among the genera included in the family Harknessellidae are, except for minor changes, the same in the two types of searches. In the four most parsimonious trees they form a large subclade, with differences affecting only to the relative position of genera. Also, the genus Kampella lays quite far from the other harknessellids and forms either a small subclade with the heterorthid Incorthis (heuristic search), or is placed together with Incorthis at the base of the subclade formed by the rest of heterorthids (branch and bound search).

The phylogenetic relationships obtained with the branch and bound search are described here (Fig. 7). The heterorthid Incorthis Havlíček \& Branisa, 1980 and the harknessellid Kampella reside at the base of the cladogram, out of the two resulting subclades, which include the remaining heterorthids and harknesellids, respectively. In fact, Incorthis is a genus of difficult placement, which lacks evidence of a punctate shell (Benedetto 2003). It was considered an orthid by Havlíček \& Branisa (1980), included provisionally within the heterorthids by Harper (2000), and suggested as being a plectorthid by Benedetto (2003). Our analysis does not support its inclusion within the family Heterorthidae. Kampella is another form with unclear taxonomic affinities, as mentioned above. Our study does not support either its assignment within the heterorthids, as proposed by Baarli (1988), or within the harknessellids, as suggested by Harper (2000).

All of the other genera included by Harper (2000) within the family Harknessellidae, with the addition of Cacemia and the new genus Isabelella, occur in a single subclade, their main synapomorphies being the subquadrate shell outline and the presence of fulcral plates and adductor pits. Isabelella is the most primitive member of the family, displaying the incurved posterolateral ribs of the primitive Paurorthis, not retained by any other harknessellid. Its first known occurrence is slightly later than those of Haymina, Horderleyella or Cacemia (see Fig. 8) but this could be related to its adaptation to a rarely preserved restricted environment: Isabelella is known from only two Darriwilian localities along the entire Mediterranean margin of Gondwana. The stratigraphic record of Cacemia, the other genus newly assigned to the harknessellids, matches the cladogram much better. Cacemia is one of the three harknessellid genera with the earliest records (middle Darriwilian), and is the second least derived genus, after Isabelella. The main autoapomorphies of Cacemia within the family are the missing fulcral plates and adductor pits, and the well-developed notothyrial platform, which can be interpreted as primitive features.

\section{Palaeobiogeographic remarks}

The earliest records of the family Harknessellidae are of mid and late Darriwilian age. By that time, the family had already experienced an important radiation and migration through the high latitude Gondwanan margins, with Cacemia and Isabelella in Ibero-Armorica and North Africa (Mélou et al. 1999, and this paper); through the mid-latitude peri-Gondwanan terrains, with Horderleyella in Avalonia (Williams 1949) and most likely South China (Zhan \& Jin 2005); and as far as Baltica, located not far from Gondwana at this time, with Haymina (Harper 2007). All of these data suggest a pre-Darriwilian origin for the group, most likely on the North African Gondwana margin, where Avalonia was still attached during that time. Our phylogenetic analysis places the Iberian Cacemia and Isabelella in basal positions of the resulting cladograms, in agreement with their early stratigraphic records. It also points to an origin for the family on the high latitude Gondwanan shelves.

During the Late Ordovician, Horderleyella continued its radiation in both Avalonia (Bancroft, 1928) and Baltica (Hints \& Harper 2003), and migrated into the Moroccan and Bohemian Gondwana margins (Havlíček 1971 and 1977). The other genera retained within the Harknessellidae also radiated during the early Late Ordovician. Reuschella had the maximum geographic extent, being known from Avalonia (Bancroft 1945), Laurentia (Cooper 1956), and Baltica (Hints \& Harper 2003), as well as from Gondwana, where it spread from Iberia (Villas 1992) to the Precordillera Argentina (Benedetto 2003). Species of Smeathenella and Harknessella have only been described from Avalonia (Bancroft 1945). The final records for the 
family correspond to Horderleyella and Reuschella, with Hirnantian species of the former genus described from Bohemia and Morocco (Havlíček 1971) and Poland (Temple 1965), and of Reuschella from the Argentinian Precordillera (Benedetto 2003).

\section{Acknowledgements}

We are grateful to Diego García-Bellido (Adelaide, Australia) for revising the English text, and to the reviewers Ian Percival and Leonid Popov for their helpful revisions improving the manuscript.This article is a contribution to Project CGL2009-09583 of the Spanish Ministry of Science and Innovation and to Project E-17 "Patrimonio y Museo Paleontológico" from the Department of Science, Technology and University of the Aragón Government, partially supported by the European Social Fund. It is also a contribution to the IGCP Project 591 "The Early to Middle Paleozoic Revolution".

\section{References}

BAARLI, B.G. 1998. The Llandovery enteletacean brachiopods of the central Oslo region, Norway. Palaeontology 31, 1101-1129.

Babin, C. \& GutiérRez-MarCo, J.C. 1991. Middle Ordovician bivalves from Spain and their phyletic and palaeogeographic significance. Palaeontology 34, 109-147.

Bancroft, B.B. 1928. The Harknessellinae. Memoirs and Proceedings of the Manchester Literary and Philosophical Society $72,173-196$.

BANCROFT, B.B. 1945. The brachiopod zonal indices of the stages Costonian to Onnian in Britain. Journal of Paleontology 19, 181-252.

BenedetTo, J.L. 2003. Brachiopods, 187-272. In BenEDETTo, J.L. (ed.) Ordovician Fossils of Argentina. Secretaría de Ciencia y Tecnología, Universidad Nacional de Córdoba.

Bergström, S.M., Chen, X., Gutiérrez-Marco, J.C. \& Dronov, A.V. 2009. The new chronostratigraphic classification of the Ordovician System and its relations to major regional series and stages and $\delta^{13} \mathrm{C}$ chemostratigraphy. Lethaia 42, 97-107. DOI 10.1111/j.1502-3931.2008.00136.x

BogoyaVlenskaya, V.M. 1991. Brachiopods, 74-105. In Puchkov, V.N. (ed.) Ordovician of the Polar Urals. Palaeontology. Uralskoye otdeleniye Akademii nauk SSSR, Sverdlovsk.

Born, A. 1918. Die Calymene tristani-Stufe (mittleres Untersilur) bei Almaden, ihre Fauna, Gliederung und Verbreitung. Abhandlungen der senckenbergischen naturforschenden Gesellschaft 36 (for 1916), 309-358.

COOPER, A.H. 1980. The stratigraphy and palaeontology of the Ordovician to Devonian rocks of the area north of Dornes (near Figueiró dos Vinhos), central Portugal. 430 pp. Unpublished PhD thesis, University of Sheffield.

Cooper, G.A. 1956. Chazyan and related brachiopods. Smithsonian Miscellaneous Collections 127(1-2), 1-1245.

Cooper, G.A. \& Muir-Wood, H.M. 1951. Brachiopod hom- onyms. Journal of the Washington Academy of Sciences 41, 195-196.

Delgado, J.F.N. 1897. Fauna Silúrica de Portugal. Novas observações ácerca de Lichas (Uralichas) Ribeiroi. Memórias da Direcção dos Trabalhos Geológicos de Portugal, 1-34.

Delgado, J.F.N. 1908. Système Silurique du Portugal. Étude de stratigraphie paléontologique. Memórias e Comunicaçoes dos Serviços Geológicos de Portugal, 1-245.

Gutiérrez-Marco, J.C., Aramburu, C., Arbizu, M., Bernárdez, E., Hacar Rodríguez, M.P., Méndez-Bedia, I., Montesinos López, R., Rábano, I., Truyols, J. \& Villas, E. 1999. Revisión bioestratigráfica de las pizarras del Ordovícico Medio en el noroeste de España (Zonas Cantábrica, Asturoccidental-leonesa y Centroibérica septentrional). Acta Geologica Hispanica 34, 3-87.

Gutiérrez-Marco, J.C., Rábano, I., Prieto, M. \& Martín, J. 1984. Estudio bioestratigráfico del Llanvirn y Llandeilo (Dobrotiviense) en la parte meridional de la zona Centroibérica (España). Cuadernos de Geología Ibérica 9, 287-319.

Gutiérrez-Marco, J.C., Robardet, M., RÁbano, I., Sarmiento, G.N., San José Lancha, M.A., Herranz AraúJo, P. \& Pieren Pidal, A.P. 2002. Ordovician, 31-49. In GibBons, W. \& Moreno, T. (eds) The Geology of Spain. The Geological Society, London.

Hammann, W., Robardet, M. \& Romano, M. 1982. The Ordovician System in southwestern Europe (France, Spain and Portugal). Correlation Chart and Explanatory Notes. International Union of Geological Sciences, Publication 11, 1-47.

Harper, D.A.T. 2000. Dalmanellidina, H782-H844. In KAESLER, R.L. (ed.) Treatise on Invertebrate Paleontology, Part H, Brachiopoda, Revised Volume 3. Geological Society of America \& University of Kansas, Boulder \& Lawrence.

Harper, D.A.T. 2007. Orthida, H2684-H2698. In SELDEN, R.L. (ed.) Treatise on Invertebrate Paleontology, Part H, Brachiopoda, Revised Volume 6. Geological Society of America \& University of Kansas, Boulder \& Lawrence.

HavlíčEK, V. 1967. Brachiopoda of the Suborder Strophomenidina in Czechoslovakia. Rozpravy Ústředního ústavu geologického 33, 334-235.

HAVLíčEK, V. 1970. Heterorthidae (Brachiopoda) in the Mediterranean Province. Sborník geologických věd, Paleontologie 33, $7-39$.

HavlíčEK, V. 1971. Brachiopodes de l'Ordovicien du Maroc. Notes et Mémoires du Service Géologique 230, 1-135.

HAVLíčEK, V. 1977. Brachiopods of the order Orthida in Czechoslovakia. Rozpravy Ústředního ústavu geologického 44, $1-293$.

HaVlíčEK, V. \& Branisa, L. 1980. Ordovician brachiopods of Bolivia (Succession of assemblages, climate control, affinity to Anglo-French and Bohemian provinces). Rozpravy Československé akademie věd 90,1-54.

Havlíček, V., KŘiž, J. \& Serpagli, E. 1987. Upper Ordovician brachiopod assemblages of the Carnic Alps, middle Carinthia and Sardinia. Bollettino della Società Paleontologica Italiana $25,277-311$.

Hints, L. \& Harper, D.A.T. 2003. Review of the Ordovician rhynchonelliformean Brachiopoda of the East Baltic: Their distribution and biofacies. Bulletin of the Geological Society of Denmark 50, 29-43. 
Maddison, W. \& Maddison, D. 2003. MacClade, v. 4.06. Sinauer Associates, Sunderland, Massachusetts.

Mélou, M. 1976. Orthida (Brachiopoda) de la Formation de Postolonnec (Ordovicien), Finistère, France. Geobios 9, 693-717. DOI 10.1016/S0016-6995(76)80075-7

Mélou, M., Oulesbir, L. \& Paris, F. 1999. Brachiopodes et chitinozoaires ordoviciens dans le NE du Sahara algérien: implications stratigraphiques et paléogeographiques. Geobios 32, 823-839. DOI 10.1016/S0016-6995(99)80865-1

MÉlou, M. \& Pillet, J. 1998. Orthida (Brachiopoda) des Schistes d'Angers (Llanvirn) du flanc nord du bassin de Saint-Julien de Voivantes. Bulletin de la Société d'Etudes scientifiques de l'Anjou 16, 89-97.

Mitchell, W.I. 1974. An outline of the stratigraphy and palaeontology of the Ordovician rocks of Central Portugal. Geological Magazine 111, 385-396.

DOI $10.1017 /$ S0016756800039947

Moore, R.C. 1952. Brachiopoda, 197-267. In Moore, R.C., Lalicker, C.G. \& FisChER, A.G. Invertebrate Fossils. McGraw-Hill, New York.

ÖPIK, A.A. 1933. Über einige Dalmanellacea aus Estland. Universitatis Tartuensis (Dorpatensis) Acta et Commentationes A 25, 1-25.

RÁBAnO, I. 1989. Trilobites del Ordovícico Medio del sector meridional de la zona Centroibérica española. Parte I. Yacimientos, bioestratigrafía y aspectos paleobiogeográficos. Boletín Geológico y Minero 100, 307-338.

REED, F.R.C. 1917. The Ordovician and Silurian brachiopods of the Girvan district. Transactions of the Royal Society of Edinburgh 51, 795-998. DOI 10.1017/S0080456800011959

Reyes-Abril, J. 2009. Braquiópodos del Ordovícico Medio de la Zona Centroibérica Meridional (España). 374 pp. Unpublished $\mathrm{PhD}$ thesis, University of Zaragoza.

Reyes-Abril, J., Gutiérrez-Marco, J.C. \& Villas, E. 2011. Biostratigraphy of the Middle Ordovician brachiopods from Central Spain, 463-472. In GutiérRez-MARCO, J.C., RÁBANO, I. \& García-Bellido, D. (eds) Ordovician of the World. Serie Cuadernos del Museo Geominero 14, Instituto Geológico y Minero de España, Madrid.

Reyes-Abril, J., Villas, E. \& Gutiérrez-Marco, J.C. 2010. Orthid brachiopods from the Middle Ordovician of the Central Iberian Zone, Spain. Acta Palaeontologica Polonica 55, 285-308. DOI 10.4202/app.2009.0032

Ribeiro, C., Sharpe, D., Salter, J.W., Jones, T.R. \& Bunbury, C.J.F. 1853. On the Carboniferous and Silurian formations of the neighbourhood of Bussaco in Portugal. Quarterly Journal of the Geological Society of London 9, 135-160.

DOI 10.1144/GSL.JGS.1853.009.01-02.28
Romão, J.M.C. 2000. Estudo tectono-estratigráfico de um segmento do bordo SW da Zona Centro-Ibérica, e as suas relações com a Zona Ossa-Morena. 323 pp. Unpublished $\mathrm{PhD}$ thesis, Universidade de Lisboa.

Schuchert, C. 1913. Class Brachiopoda. The Lower Devonian deposits of Maryland. Maryland Geological Survey, Baltimore, 290-449.

SChuchert, C. \& Cooper, G.A. 1931. Synopsis of the brachiopod genera of the suborders Orthoidea and Pentameroidea, with notes on the Telotremata. American Journal of Science 222, 241-251. DOI 10.2475/ajs.s5-22.129.241

Schuchert, C. \& Cooper, G.A. 1932. Brachiopod genera of the suborders Orthoidea and Pentameroidea. Memoirs of the Peabody Museum of Natural History 4, 270 pp.

Swofford, D.L. 2002. PAUP*. Phylogenetic Analysis Using Parsimony (*and Other Methods). Sinauer Associates, Sunderland, Massachusetts.

Temple, J.T. 1965. Upper Ordovician brachiopods from Poland and Britain. Acta Palaeontologica Polonica 10, 379-427.

Tromelin, G.L. DE \& Lebesconte, P. 1876. Essai d'un catalogue raisonné des fossiles siluriens des départements de Maine-et-Loire, de la Loire-Inférieure et du Morbihan, avec des observations sur les terrains Paléozoïques de l'Ouest de la France. Comptes Rendus du 4ème Session de la Association Française pour l'Avancement des Sciences, Nantes, 601-661.

Verneuil, E. DE \& BarRande, J. 1855. Description des fossiles trouvés dans les terrains Silurien et Dévonien d'Almadén, d'une partie de la Sierra Morena et des Montagnes de Tolède. Bulletin de la Société Géologique de France, 2ème série 12, 964-1025.

ViLLAS, E. 1992. New Caradoc brachiopods from the Iberian Chains (Northeastern Spain) and their stratigraphic significance. Journal of Paleontology 66, 772-793.

Williams, A. 1949. New Lower Ordovician brachiopods from the Llandeilo-Llangadock District. Geological Magazine 86, 161-174. DOI 10.1017/S0016756800074525

Williams, A. \& Harper, D.A.T. 2000. Orthida, H714-H782. In KAESLER, R.L. (ed.) Treatise on Invertebrate Paleontology, Part H, Brachiopoda; Revised Volume 3. Geological Society of America \& University of Kansas, Boulder \& Lawrence.

ZHAN, R.-B. \& Jin, J. 2005. Brachiopods from the Middle Ordovician Shihtzupu Formation of Yunnan Province, China. Acta Palaeontologica Polonica 50, 365-393.

Zнu, C.-Y. 1985. Late Ordovician Brachiopoda from Wulongtun district of eastern Da Hinggan Ling region, northeast China. Bulletin of the Shengyang Institute of Geology and Mineral Resources, Chinese Academy of Sciences 12, 24-54. [in Chinese, English abstract] 